\title{
TEACHERS' UNDERSTANDING TOWARDS PORTFOLIO ASSESSMENT: A CASE STUDY AMONG MALAYSIAN PRIMARY SCHOOL TEACHERS
}

\author{
Kalai Selvan Arumugham \\ Tunku Seri Indera Putera High School, Malaysia \\ E-mail: kalvan_80@yahoo.com
}

\begin{abstract}
Alternative assessment plays an important role in gathering information about students' learning. Introduction of new curriculum in Malaysian primary school education namely Standard Curriculum of Primary School has highlighted portfolio as an assessment tool. Therefore, research has been conducted to examine teachers' understanding towards this new alternative assessment method. The qualitative data used in this research were gathered from three interview sessions and classroom observations. Five primary school teachers were selected as participants of this research. They are teaching core subject such as English, Mathematics and Science. Thematic analysis was conducted to examine the themes emerged to represent their understandings towards portfolio. Teachers'understandings towards portfolio were grouped into three major themes: As students' work collections, as feedback and improvement tools and as teaching, learning and grading tools. They used portfolio in classroom as they understood. Different understandings were revealed as these teachers are also teaching different subjects. This may be the reason why these teachers were having different understandings towards portfolio assessments. This research is significant to teachers, stakeholders, school administration and even society about portfolio assessment.
\end{abstract}

Keywords: classroom assessment, learning process, portfolio assessment, teachers' understanding.

\section{Introduction}

All over the world, a number of countries are reforming their educational systems from being centralized examination system to School-Based Assessment (SBA). In order to achieve this, formative assessment method has been given more priority compared to summative assessment and if it is correctly implemented, it can engage students in the learning process (Sidhu, Chan, and Sidhu, 2011; Shepard 2000). One of the methods that has been used widely in conducting formative assessment is portfolio assessment (Birgin \& Baki, 2009; Hamilton, 2011). Portfolio gives more reliable and dynamic data about students for teachers, parents and also students themselves (Arter, 1999). Portfolio assessment method especially in primary schools provides clear information about students and helps teachers to plan their teaching and learning activities more effectively (Borhan, 2005).

Portfolio can present a wide perspective of learning process for students and enables an ongoing feedback for them (Charoenchai, Phuseeorn, \& Phengsawat, 2015; Zhang, 2009). Besides, portfolio also enables students to have a self-assessment for their studies and learning (Gavriel, 2013). Portfolio also can provide visual and dynamic proofs about students' interests, their skills, strong sides, successes and development in a certain time period, portfolio which is the systematic collection of the students' studies helps assessing students as a whole (Birgin \& Baki, 2009).

Many previous studies have been conducted on portfolio assessment. Charvade, Jahandar, and Khodabandehlou (2012) studied 50 students in EFL classroom. An experimental 
Kalai Selvan ARUMUGHAM. Teachers' understanding towards portfolio assessment: A case study among Malaysian primary school teachers

PROBLEMS

OF EDUCATION IN THE $21^{\text {st }}$ CENTURY Vol. 77, No. 6, 2019

696

design study which has been done by dividing the students into experimental and controlled group revealed that the students in the experimental group outperformed the students in the control group in their reading comprehension ability. Since this research has been done in EFL classroom, the researchers suggested that portfolio assessment should be applied in some other subjects as it has a potential to develop students' learning process.

Zhang (2009) has conducted a study on the use of portfolio in Chinese context. The study has been done among English teachers. Questionnaire and interviews were used in the process to gather data. Quantitative data revealed that teachers have been using portfolio as an assessment tool widely as they can keep on track on their students' learning process, while qualitative data indicate that teachers prefer to use portfolio as they can differentiate students' ability and it has become students' learning evidence.

Ugodulunwa and Wakjissa (2015) aimed to investigate portfolio assessment technique in teaching geography. The quasi-experimental design study has been conducted in two schools in Jos South, Nigeria. Students were divided into experimental and controlled group. Findings from this study revealed that portfolio assessment helped in improving students' performance in map sketching and location where the experimental group recorded higher mean gain scores of 33.32 as against 1.65 from controlled group.

A recent study done by Samad, Hussin, and Sulaiman (2015) was done among Malaysian ESL teachers. The study intended to determine the techniques ESL teachers use in implementing portfolio as an assessment tool. These researchers proposed a model of portfolio assessment since there was no specific model or technique to conduct portfolio assessment in Malaysia. Furthermore, Samad, Hussin, and Sulaiman (2015) have stated that, in Malaysia portfolio assessment was heard, but not widely used. Semi-structured interviews and classroom observations from nine ESL teachers were utilized in order to collect data. Findings revealed that, portfolio model developed has provided ESL teachers the opportunity to document individual student's growth.

The findings from all of these studies revealed that portfolio assessment has many advantages comparing with standardized testing. Portfolio assessment enables measuring high level skills with meaningful for a certain period of time comparing to standardizing test which will be tested in a certain period (Arter, 1999). Besides, portfolio assessment can give a chance for teachers to give some feedback for students for their learning process and make affective communication with teachers and even their parents.

In summary, portfolio assessment provides more authentic and valid assessment of students' achievement. It can give a clearer picture to teachers, parents and even to the students themselves on what they are learning. Teachers also will have an opportunity to give feedback to students about their strength and weakness. In addition, portfolio assessment has a potential to demonstrate students' learning process and learning product over time. As a result, it can give detailed information about students' development in the learning process.

\section{Research Problem}

Realizing these needs, Malaysian Education Ministry also has introduced Portfolio assessment through the newly implemented curriculum known as Standard Curriculum of Primary School. Through this curriculum, assessment will be conducted in school level in order to gain information about students' ability and allowing teachers to provide ongoing feedback for students to help them to improve on their learning process. In Malaysia portfolio assessment has been introduced since 2017 , so the purpose of this research is to identify primary school teachers' understanding towards portfolio assessment and how they are using this portfolio in their teaching process. Furthermore, most of the past studies that have been discussed earlier seem to be more on the implication on portfolio uses in teaching and learning. To achieve this 
aim, some information of portfolio such as definition, types of portfolio and its advantage and disadvantage were discussed in depth. Studying teachers' perceptive of portfolio assessment is important because evidence suggests that teachers' understandings of teaching and learning strongly influence how they teach and what students learn and achieve (Frohbieter, Greenwald, Stecher, and Schwartz, 2011; Mullin, 1998; Wiliam, 2010). To illustrate Samad, Hussin, and Sulaiman's (2015) case study of assessment in Secondary School English classes revealed an eclectic array of conflicting assessment practices, seemingly because the teachers held differing perceptions of teaching and student learning. Similarly, research suggests that changes in formative assessment practices are directly related to the changes in teachers' attitudes (Dekker $\&$ Feijs, 2005; Gavriel, 2013). Therefore, it is imperative that there is a need to study on teachers' understanding before implementing changes at in-service teachers.

\section{Research Focus}

This qualitative case study approach explores a group of teachers' understanding of portfolio assessment and how they have used portfolio in classroom teaching and learning.

\section{Research Methodology}

\section{General Background}

The aim of this research was to explore in depth teachers' understanding of portfolio assessment and how they integrated it into their teaching and learning process. In order to get deep understanding on this issue, researcher chooses to use qualitative case study method. Qualitative research is one of the methods that can help the researcher to investigate the matter of the study deeply (Braun \& Clark, 2013). In this case, researcher has been with the participants for six months in order to conduct an interview and observations.

\section{Sample}

Using purposive sampling method, five primary school teachers teaching the core subject (English, Science \& Mathematics) and who were directly using portfolio as an assessment tool were selected to participate in this research. The number of participants was not determined prior to data collection; instead, it depended on the resources and time available as well as the iterative nature of qualitative data collection (Creswell, 2013). For confidentiality reasons, in this research the teacher identified were Hasanah, Jamaliah, Patrick, Premila and Aruna. Hasanah, Premila and Aruna have been teaching for more than ten years, while Patrick and Jamaliah have taught for less than ten years.

\section{Data Collection and Analysis Procedure}

Semi-structured interviews were conducted based on an interview protocol. The interview questions were reviewed by the expert to ensure that the participants understood them and were able to respond. The teachers were interviewed three times throughout this research to ensure consistencies in their responses. Following each round of the interviews, data were analyzed for recurrent themes based on a priori categories and emergent categories to reflect the teachers' understanding of portfolio assessment. Classroom observations were also conducted to examine how teachers used portfolio in teaching, learning and assessment. The researcher took notes of all the steps done by the teacher during the observation process. This observation helped the researcher to validate data collected via semi structured interview. In

\author{
PROBLEMS \\ OF EDUCATION \\ IN THE $21^{\text {st }}$ CENTURY \\ Vol. 77, No. 6, 2019 \\ 697
}


Kalai Selvan ARUMUGHAM. Teachers' understanding towards portfolio assessment: A case study among Malaysian primary

school teachers

PROBLEMS

OF EDUCATION

IN THE $21^{\text {st }}$ CENTURY

Vol. 77, No. 6, 2019

order to minimize the researchers' influence on the data collected, each teacher was observed for multiple times.

Data were analyzed manually in two phases. In the first phase, the researcher took notes on the main point while data were collected. The second phase analysis was done after the researcher completed the whole data collecting process. All the main phases were coded and categorized according to the research questions and objectives. Finally, the themes were developed according to the frequency of the phrases.

\section{Research Results}

\section{Interview Results}

Data analysis of the teachers' understanding of portfolio assessment revealed the following themes: portfolio as a students' work collection, portfolio as a feedback tool and portfolio as a teaching, learning and grading tool.

\section{Students Work Collection}

Patrick and Aruna, who teach Science for year three students, have been using portfolio to keep their students' task throughout their teaching and learning process. They compiled all the work in one hard covered file named students' portfolio.

For me portfolio is just a file to compile students' task throughout the teaching process (INT 2/ Patrick).

Portfolio is more than a file that teachers need to use to keep students'work (INT 2/Aruna).

For both of them portfolio is a file that they are using to compile all students' work throughout the teaching process. In their case, they are not using any exercise books. Both of them prepared worksheet for each lesson.

I'll ask my students to keep all the worksheets inside the file as the stakeholders ask us to do so (INT1/Patrick)

For me better my students to keep all the worksheets inside the file because this is what the stakeholders ask us to do (INT1/Aruna).

Both of them are doing the same by asking the students to keep all the worksheets inside the file as it is requested by the stakeholders. Patrick and Aruna are also looking at portfolio as a file to compile all students' work. Both of them prefer to keep students' work inside the portfolio as it will be the students' learning evidence if there is any supervision.

I like to keep everything inside the portfolio as it will be easy for me to show all this evidence if there is any supervision (INT3/Patrick).

Stakeholders are always looking for students'evidence, so that I like to keep all my students'work in their portfolio. I can show it during any supervision (INT2/Aruna).

Both of them are very alert on school supervision by stakeholders. They realize that the stake- holders are looking for students' learning evidence. During the supervision, they will show the portfolio to the stakeholders as a proof of teaching and learning process. As Patrick 
and Aruna are teaching Science, they have many work tasks and they make use of the portfolio as a tool to compile all the worksheet.

In this case both Patrick and Aruna have understood portfolio as a file to compile student works. In that case, their practice also seems to be like what they have understood. They are more concerned on supervision as the stakeholders need teaching evidence as a proof of teaching and learning process. In their case, portfolio doesn't seem to be a learning tool but more on collecting student's evidence. Both of them didn't ask the students to bring their portfolio; instead they collected the work tasks and filed them into students' portfolio.

I won't give the portfolio to the students, but I will do all the filing for them. I keep the file in the SBA room, so anyone can access the portfolio (INT3/Patrick).

I didn 't return the portfolio to students. I keep at school so the administrative can monitor students' work (INT2/Aruna).

In summary it can be concluded that both Patrick and Aruna understood portfolio as a tool to keep students' learning evidence for supervision purpose. Their understanding makes them emphasize portfolio as a tool to compile students' work.

\section{Feedback and Improvement Tools}

Hasanah and Jamaliah who are teaching mathematics, understood portfolio as a feedback and improvement tool. Hasanah is teaching mathematics for year two students, while Jamaliah teaches year three. Both of them are working in the same school with different teaching experience. Hasanah and Jamaliah did not use portfolio to keep the entire task as done by Patrick and Aruna, but they chose the task to be kept inside the portfolio.

Portfolio is more to give grading for students towards the end of the year, so that I won't ask students to keep all the task, instead I will choose the essential one to keep inside the portfolio (INT1/Hasanah).

Only certain tasks will be in my students' portfolio. It depends on the need for assessment criteria. Normally I ask students to keep materials related to their topical assessment (INT2/Jamaliah).

The way that these teachers understood about portfolio is totally different comparing to the previous teachers. Their understanding towards portfolio assessment is more likely as showcase portfolio. They prefer to select certain tasks to be kept in the portfolio as they can use these tasks for grading purposes. As has been mentioned in literature, there are many types of portfolio and these teachers have understood portfolio in this way.

I like to select task to be kept in portfolio as this task has been used for feedback purpose. Due to time constraint I used to choose task and provide feedback for students' improvement, so I ask my students only to keep task that I've used to give feedback for improvement (INT3/Hasanah).

Some tasks are not suitable to be kept in the portfolio. I like to choose the materials that are involved in the improvement process, so I can get a clear picture on that particular student (INT2/ Jamaliah).

Hasanah and Jamaliah perceived portfolio as a tool for students' improvement. These teachers used to give feedback for the students' improvement. As they just need to know the students' progression on certain area, so they asked the students to keep only the relevant task inside the portfolio. These teachers are doing so as they need to know about the students' 
Kalai Selvan ARUMUGHAM. Teachers' understanding towards portfolio assessment: A case study among Malaysian primary school teachers

PROBLEMS

OF EDUCATION

IN THE $21^{\text {st }}$ CENTURY Vol. 77, No. 6, 2019

700

learning process at the same time they can measure the students' progression for final grading. During the classroom observation, students of both Hasanah and Jamaliah bring portfolio each time they have their mathematics lesson but use it when there is a need. They are still using exercise and workbooks instead of portfolio.

In summary Hasanah and Jamaliah understood portfolio as a tool to provide feedback for students. They asked students to keep the important task with some feedback for improvement purpose.

\section{Teaching, Learning and Grading Tools}

Premila is looking at portfolio as a blended teaching, learning and grading tools. For Premila, she will use portfolio throughout her teaching process. Students need to bring their portfolio each time during the English lesson. Premila who has been teaching English for year 2 and 3 for more than ten years perceived that portfolio works as a teaching and learning tool. For her perspective as a teacher, she can provide materials for her students to be kept in portfolio and even she can ask students to find suitable materials for classroom activities.

Portfolio is something very unique! I've utilized for many purposes, such as teaching, learning and even to give a grade for students. During my lesson, I'll provide my students with necessary task and even I'll ask them to bring their own materials, such as newspaper cuttings, pictures, and sometimes material from internet. All these things I will use for my teaching and students learning purposes. End of the year I will use their portfolio to grade them (INT2/Premila).

Premila has understood that portfolio must be used throughout the lesson. Students need to bring their portfolio each time of the lesson and they must use it for learning purpose. At the early stage, Premila used portfolio for her teaching process. She also assumed portfolio is a tool that can help students to learn a lesson from the beginner level to an advanced level. For an example, she used to start teaching essay writing from constructing sentences. She will provide words and pictures to stimulate student's idea on how to write sentences. After students were able to construct sentences, she will move on to the next writing level. At this stage, she will teach students to write a short paragraph. She carried out the lesson until students were able to write a complete essay. For Premila, portfolio is a tool where students can learn from one level to another level. In teachers' perspective she can assess students continuously throughout the learning process.

I always repeat this process until I'm satisfied with my students' writing. It is not easy to teach writing for students with different background, since it is a long process, I prefer to use portfolio to keep on track about the writing improvement. For example, let's say I have four lessons on writing, so with students' portfolio I can check through all the four lesson activities to get a picture on students'learning progression (INT3/Premila).

Premila used portfolio to identify students' strength and weakness. From this report, she can do a further step and plan for her teaching. If she feels that the students need to work more on that particular lesson, she will do some extra activities to help her students, otherwise she can move on to the next lesson. Besides, she also asks students to find materials for the learning process. For students' learning process, she asks students to find relevant materials for their own learning. 
Observation process was carried out to validate the data collected via interview. This process was done while teachers are teaching in classroom. Researcher observed on how teachers are using portfolio as an assessment tool and cross check the field note with their interview transcript. Patrick and Aruna who understood portfolio as the students' work collection are only using portfolio to compile the students' task. Throughout the classroom teaching and learning process, students did not use any exercise book. These teachers prepare the task for students. During the teaching and learning process, Patrick and Aruna used the task to do discussion and explained each of the aspects to the students. Once the discussion done, Patrick and Aruna collected the task and they compiled it inside the students' portfolio. This process is as they mentioned in their interview. To enhance the validity of the observation data, the researcher did observation three times. All the three times, both of these teachers did the same process.

Okay students, you can return your task now. I will keep it inside your portfolio. (FN1/Patrick)

Students, you need to submit your enrichment task. As usual I will keep it inside your portfolio. (FN2/Aruna)

Hasanah and Jamaliah who perceived portfolio as a feedback and improvement tool also did the same things during the observation process. Both of these teachers conduct their lesson as they planned. At the end of the teaching and learning process, they provide the task for the students. They will give approximately ten to fifteen minutes for the students to complete the task. This has been done during all the observation process. They collected the task once the allocated time finished. During the next lesson, teachers returned the task for the students with some feedback and comment provided on the task. Before they started the lesson, they provided feedback for the command mistakes done by the students and they provided additional task for the students for improvement purpose. Every ten to fifteen minutes they spent providing feedback for the assessment purpose. Even though there are many assessment activities, but these teachers chose only the selected tasks to be kept inside the portfolio. Throughout the three observations, they carried out the same process.

Okay students, out of the three enrichment activities please send me the one you achieved the highest band. (FN3/Hasanah)

Students all the while I had taught you increasing and decreasing numbers. We had done few for this topic and you have all of it. Please submit all the tasks and teacher will choose the one you got the highest band and keep inside your portfolio. (FN3/Jamaliah)

The field note shows that both of these teachers selected only the material with the highest band to be kept inside the file. This may be requested by the stakeholders to compile the evidence for the assessment purpose.

Premila who understood portfolio as the teaching, learning and grading tool used portfolio for all these purposes. From the observation, during her writing lesson with year three students it was observed that she provided students with tasks such as pictures, words with some graphics, and some example of sentences. Later she asked the students to tell about the pictures orally and pronounce the listed words. She also asked students to classify the words according to the pictures. As an enrichment activity, she asked the students to write sentences based on the words and the pictures and she collected the tasks. 
PROBLEMS

OF EDUCATION

IN THE $21^{\text {st }}$ CENTURY

Vol. 77, No. 6, 2019

702

Students, you need to use all these words to write a short paragraph based on the picture given. It is advisable for you to check the grammar to avoid the grammatical mistakes (FN2/Premila)

Later when the researcher observed her for the next lesson, she returned the task to the students and gave feedback on their writing. She even wrote some sentences taken from the students' works to show and the students copied them. From this process she taught her students based on the mistakes done by them. After she had done with this step, she asked the students to keep this task inside the portfolio. The next step, she asked the students to exchange the portfolio with the student who was sitting next to them to share how their friends constructed sentences. During this process, she observed the students and guided them. Towards the end of the lesson, Premila asked the students to find a picture about a wedding ceremony and asked them to construct five sentences based on the wedding ceremony picture. She used portfolio for her teaching and learning process. She compiled the entire task in students' portfolio and finally she used the portfolio to provide grades for the students.

\section{Discussion}

In a nutshell, there are three themes revealed from this study. Teachers understood portfolio as students' work collection file, as a feedback tool and as a teaching, learning and grading tool. Out of these three themes two of them have been discussed thoroughly in some previous studies. Arter \& Spandel (1992) and Collins (1992) clearly stated that portfolio can be students' compilation file. Teachers can keep students' task according to the teaching and learning progression. This was done by Patrick and Aruna. They compiled the entire task in one file named portfolio. They used the portfolio if there is any supervision from the stakeholders. However, the main aim of portfolio assessment introduction by Malaysian Ministry of Education (MOE) is more on introducing portfolio as an ongoing assessment tool. Both interview and observation data reported that these teachers understood and used portfolio to compile all the students' tasks. This shows that there is some dilution of information for them regarding the purpose on portfolio introduction. Teachers perceived portfolio as a compilation file if they did not look at the deeper meaning of portfolio assessment (Simon \& Forgette-Giroux, 2000). In this context both of them only understood portfolio as a file rather than an assessment tool.

The second theme revealed from this study also has been discussed in a few studies. Portfolio as a feedback and improvement tool has been discussed deeply by Clark (2012) and Thanh Pham \& Renshaw (2015). Findings from these studies indicated that portfolio can be a learning improvement tool. This finding aligns with what have been discussed by Hasanah and Jamaliah. Both of these teachers used to give feedback for students based on the classroom activities. The given feedback can be used for improvement purpose. However, they only keep selected materials in students' portfolio. Teachers need to compile all the materials throughout their teaching process so it can be evidence if there is any need (Arter, 1999; Stiggins \& Chappuis, 2012). This seems to be contrast as Hasanah and Jamaliah selected only the materials with high score to be kept inside the portfolio. It also shows that there is a dilution of information regarding portfolio to these teachers.

The third theme is portfolio as a teaching, learning and grading tool. This has been understood by Premila. She was looking at portfolio as a blend of these three things. Previously findings have been reported that portfolio can be used for teaching and learning but not as a grading tool (Ash \& Levitt, 2003). However, in this study, findings revealed that portfolio can be used for grading purposes. It may happen in local context because MOE stated the final stage of portfolio assessment is a grading purpose. If compared to other countries, mostly they used portfolio for the two main agenda that is teaching and learning, but in Malaysian context, it has been expanded into grading purpose. 
Apart from these, findings from this study also show that the subject that the teachers are teaching also influenced their understanding towards portfolio. Patrick and Aruna those who are teaching science understood portfolio as a compilation file while Hasanah and Jamaliah who are teaching Mathematics understood portfolio as a feedback and improvement tool. However, Premila who is teaching English, understood portfolio as a blended teaching, learning and grading. In this matter, a deep investigation should be done to find out the way how they attended the courses during the curriculum change. This is because the information they have gained may be different while they attended the in-house training.

\section{Conclusion and Implications}

In summary, portfolio in Malaysian context revealed a new finding rather than only was used for teaching and learning. Findings from this study indicated that portfolio can be used as a grading tool. While teachers are conducting classroom assessment, they can look into students' learning process which can finally be turned for grading purpose. However, overall teachers in Malaysia who are implementing this curriculum change need to have a deeper understanding towards this portfolio assessment. It is because; the dilution of information may affect the aim of this alternative assessment introduction. In this case, the stakeholders need to make sure teachers have been provided complete information regarding portfolio assessment. Stakeholders need to provide ongoing training to enhance teachers' understanding towards the changes in policy.

The findings of this study compel the researchers to purpose two primary recommendations concerning portfolio assessment. First, educational researchers must investigate whether there is any difference in using portfolio within these three core subjects. As seen in this study, there is a different understanding within these teachers as they are teaching different subjects. Patrick and Aruna who are teaching Science perceived portfolio as students' work compilation file, Hasanah and Jamaliah who are teaching Mathematics perceived it as a feedback tool while Premila who has been teaching English perceived portfolio as a teaching, learning and grading tool. In this case, there is a need for future educational researchers to identify whether there should be any differences in using portfolio among these subjects.

The second recommendation to be suggested from this study is to investigate the implementation of portfolio in students' perspective. Since this study has been done from teachers' perspective, there is also a need to get students' understanding towards this portfolio assessment. Educational research needs to be done in both students' and teachers' perspective as both of them play a crucial role in molding a good education system.

\section{References}

Arter, J. (1999). Teaching about performance assessment. Educational Measurement: Issues and Practice, 18(2), 30-44.

Arter, J. A., \& Spandel, V. (1992). Using portfolios of student work in instruction and assessment. Educational measurement: Issues and Practice, 11(1), 36-44.

Ash, D., \& Levitt, K. (2003). Working within the zone of proximal development: Formative assessment as professional development. Journal of Science Teacher Education, 14(1), 23-48. doi:10.1023/A:1022999406564.

Birgin, O., \& Baki, A. (2009). An investigation of primary school teachers' proficiency perceptions about measurement and assessment methods: The case of Turkey. Procedia-Social and Behavioral Sciences, 1(1), 681-685. https://doi.org/10.1016/j.sbspro.2009.01.119.

Borhan, L. (2005). The development of children's cognition through social interaction. Masalah pendidikan, 28, 13-20.

Braun, V., \& Clarke, V. (2013). Successful qualitative research: A practical guide for beginners, Los Angeles, America: Sage publications. 
Kalai Selvan ARUMUGHAM. Teachers' understanding towards portfolio assessment: A case study among Malaysian primary school teachers

PROBLEMS

OF EDUCATION IN THE $21^{\text {st }}$ CENTURY Vol. 77, No. 6, 2019

704

Charoenchai, C., Phuseeorn, S., \& Phengsawat, W. (2015). Teachers development model to authentic assessment by empowerment evaluation approach. Educational Research and Reviews, 10(17), 2524-2530. doi: 10.5897/ERR2015.2243.

Charvade, K. R., Jahandar, S., \& Khodabandehlou, M. (2012). The impact of portfolio assessment on EFL learners' reading comprehension ability. English Language Teaching, 5(7), 129. doi:10.5539/elt. v5n7p129.

Clark, I. (2012). Formative assessment: A systematic and artistic process of instruction for supporting school and lifelong learning. Canadian Journal of Education, 35(2), 24-40.

Collins, A. (1992). Portfolios for science education: Issues in purpose, structure, and authenticity. Science Education, 76(4), 451-463.

Creswell, J. W. (2013). Research design: Qualitative, quantitative, and mixed methods approaches, Los Angeles, America: Sage publications.

Dekker, T., \& Feijs, E. (2005). Scaling up strategies for change: Change in formative assessment practices. Assessment in Education, 12(3), 237-254. https://doi.org/10.1080/09695940500337215.

Frohbieter, G., Greenwald, E., Stecher, B., \& Schwartz, H. (2011). Knowing and Doing: What Teachers Learn from Formative Assessment and How They Use the Information. CRESST Report 802. Retrieved from https://eric.ed.gov/?id=ED522825.

Gavriel, J. (2013). Assessment for learning: A wider (classroom-researched) perspective is important for formative assessment and self-directed learning in general practice. Education for Primary Care, 24(2), 93-96. https://doi.org/10.1080/14739879.2013.11493462.

Hamilton, L. S. (2011). Testing what has been taught: Helpful, high-quality assessments start with a strong curriculum. American Educator, 34(4), 47-52. Retrieved from https://www.aft.org/sites/ default/files/periodicals/Hamilton.pdf.

Morales, L., \& Soler-Dominguez, A. (2015). Using eportfolios to encourage responsible feedback. Higher Learning Research Communications, 5(3), 14. doi:10.18870/hlrc.v5i3.245.

Mullin, J. A. (1998). Portfolios: Purposeful collections of student work. New Directions for Teaching and Learning, 7(4), 79-87.

Samad, A. A., Hussin, H., \& Sulaiman, T. (2015). Developing a portfolio assessment model for the teaching and learning of English in Malaysian L2 classroom. English Language Teaching, 8(7), 164. doi: $10.5539 /$ elt.v8n7p164.

Shepard, L. A. (2000). The role of assessment in a learning culture. Educational Researcher, 29(7), 4-14. https://doi.org/10.3102\%2F0013189X029007004.

Sidhu, G. K., Chan, Y. F., \& Sidhu, S. K. (2011). Students' reactions to school-based oral assessment: Bridging the gap in Malaysia. Asian EFL Journal, 13(4), 300-327.

Simon, M., \& Forgette-Giroux, R. (2000). Impact of a content selection framework on portfolio assessment at the classroom level. Assessment in Education: Principles, Policy \& Practice, 7(1), 83-100.

Stiggins, R. J., \& Chappuis, J. (2012). An introduction to student-involved assessment for learning (pp. 29-30). Boston: Pearson.

Thanh Pham, T. H., \& Renshaw, P. (2015). Formative assessment in Confucian heritage culture classrooms: Activity theory analysis of tensions, contradictions and hybrid practices. Assessment \& Evaluation in Higher Education, 40(1), 45-59. https://doi.org/10.1080/02602938.2014.886325.

Ugodulunwa, C., \& Wakjissa, S. (2015). Use of portfolio assessment technique in teaching map sketching and location in secondary school geography in Jos, Nigeria. Journal of Education and Practice, 6(17), 23-30.

Wiliam, D. (2010). Standardized testing and school accountability. Educational Psychologist, 45(2), $107-$ 122.

Zhang, S. (2009). Has portfolio assessment become common practice in EFL classrooms? Empirical studies from China. English Language Teaching, 2(2), 98.

Received: May 01, 2019

Accepted: November 05, 2019

Kalai Selvan Arumugham
PhD, Head of Department, Tunku Seri Indera Putera High School, 570, Taman Tunku Sarina, Jalan Atira 5, Kedah, Malaysia. E-mail: kalvan_80@yahoo.com 